\title{
BBS News:
}

\section{Award Ceremony and Seminar on Practicing Bioethics in Bangladesh}

Bangladesh Bioethics Society in collaboration with Bangladesh Bureau of Statistics organized the "Award Ceremony and Seminar on Practicing Bioethics in Bangladesh" on 4th June, 2014 at $10 \mathrm{am}$ at Bangladesh Bureau of Statistics Auditorium, Agargoan, Dhaka.

Hasanul Haq Inu, Honorable Minister, Ministry of Information, People's Republic of Bangladesh was the Chief Guest in this programme.

Ifftekharuzzaman, Executive Director, TIB; K Siddique-e-Rabbani, Professor \& Chairperson of Biomedical Physics \& Technology, University of Dhaka and Prof. Ahmad A.N. Neaz, Professor of Economics, American International University-Bangladesh delivered lecture in the seminar.

SA TV and Radio Aamar were the media partners of this Programme. Programme was sponsored by MARCEL and Bangladesh Ayeen Samity.

\section{Art / Photography Competition on ethics}

Bangladesh Bioethics Society organized an Art / Photography Competition on ethics to develop ethical values among young generation. The theme of the competition was "Ethics and life". Sub themes were what is good and bad; beauty of good behavior; appreciation of human life; discover truth about humanity and recognize inherent dignity of human. Undergraduate and Postgraduate Bangladeshi students of age between 18 to 25 years were the participants in this competition.

Md. Reaz Mahmood, MBA student, Northerrn University, Dhaka; Kaniz Fatema, BBA, $5^{\text {th }}$ Semister, Northerrn University, Dhaka and Samina Ferdousi, $2^{\text {nd }}$ Year, BDS student, City Dental College, Dhaka were adjusted $1^{\text {st }}, 2^{\text {nd }}$ and $3^{\text {rd }}$ position respectively in Fine Art / cartoon category. Tofazzal Hossain (sourav), Student of LL.M, Department of Law, University of Dhaka stood $1^{\text {st }}$ in photography category.

\section{Bioethics Awards:}

BBS recogniges those who have efforts to promote bioethics in Bangladesh and have outstanding contribution to BBS from 2014. In appreciation of dedicated work for the society Prof Taslima Monsoor, Professor \& Dean, Faculty of Law, DU \& President, Bangladesh Bioethics Society; Dr Arif Hossain, Founding Chairman \& Vice President, Bangladesh Bioethics Society and Prof Shamima Lasker, Professor \& Head of Anatomy, City Dental College, Dhaka \& Founding 
Chairman \& Secretary General, Bangladesh Bioethics Society were awarded Bioethics award for the year of 2014.

\section{Best Volunteer Award:}

In recognition of dedicated work \& organization skills, Bangladesh Bioethics Society awarded Best Volunteer Award to Atia Mannan Bushra, $4^{\text {th }}$ year BDS student; Farin Binte Rahman, $3^{\text {rd }}$ year BDS student; Ataur Rahman Bhuyan, $3^{\text {rd }}$ year BDS student and Taslim Bin Hasan, $2^{\text {nd }}$ year BDS student for the year of 2014. They all are the students of City Dental College, Dhaka. 